\title{
Characterization of Bacterial Mannanase for Hydrolyzing Palm Kernel Cake to Produce Manno-oligosaccharides Prebiotics
}

\author{
W. Utami ${ }^{a}$, A. Meryandini ${ }^{\mathrm{b}, *}$, \& K. G. Wiryawan ${ }^{\mathrm{c}}$ \\ ${ }^{a}$ Major Program of Biotechnology, Graduate School, Bogor Agricultural University \\ bDepartment of Biology, Faculty of Mathematic and Sciences, and Research Centre for Bioresources and \\ Biotechnology, Bogor Agricultural University \\ 'Department of Nutrition and Feed Technology, Faculty of Animal Science, Bogor Agricultural University \\ Kampus IPB Darmaga, Bogor 16680, Indonesia \\ (Received 17-04-2012; Reviewed 06-05-2013; Accepted 26-11-2013)
}

\begin{abstract}
Palm kernel cake (PKC) is a promising source of prebiotics, since it contains high amount of $\beta$ mannan which can be further hydrolyzed to manno-oligasaccharides (MOS), a prebiotic. Therefore, this research was carried out to analyze the capability of a bacterial isolate (A2 isolates) previously isolated from soils sample from around IPB campus to hydrolyze PKC. Based on 16S-DNA analysis, isolate A2 was identified as Brevibacillus borstelensis. Mannanase of A2 isolate had an optimum condition at $90{ }^{\circ} \mathrm{C}$ and $\mathrm{pH}$ 7. Mannanase activity of crude extracts using Locust Bean Gum (LBG) and PKC as substrates were $0.37 \mathrm{U} / \mathrm{mL}$ and $0.032 \mathrm{U} / \mathrm{mL}$, respectively. However, the most favorable production of oligosaccharides based on the degree of polymerization was obtained after 72-h of incubation with the ratio of substrate:enzyme, 1.2:1, on 1.5\% PKC as substrate. The manno-oligosaccharides prebiotic obtained was found to interfere the growth of both lactic acid bacteria (Lactobacillus casei) and pathogenic microflora (Escherichia coli). E. coli apparently could not use this prebiotic as the carbon sources, in contrast to L. casei. Substitution of carbon source in medium with prebiotics reduced the capability of $L$. casei to produce organic acids. It is concluded that local A2 isolate (B. borstelensis) produces mannanase which can be used to produce prebiotics from PKC.
\end{abstract}

Key words: Brevibacillus borstelensis, mannanase, Lactobacillus casei, PKC

\section{ABSTRAK}

Komponen utama dari bungkil inti sawit (BIS) adalah $\beta$-manan yang dapat digunakan dalam produksi prebiotik Manno-oligosakarida (MOS). Penelitian ini bertujuan mengkarakterisasi kemampuan isolat bakteri A2 yang diisolasi dari sampel tanah di sekitar kampus IPB dalam mendegradasi BIS. Berdasarkan analisis 16S-DNA isolat A2 teridentifikasi sebagai Brevibacillus borstelensis. Mananase isolat A2 memiliki kondisi optimum pada suhu $90^{\circ} \mathrm{C}$ dan $\mathrm{pH}$ 7. Aktivitas mananase isolat A2 pada media dengan Locust Bean Gum (LBG) dan BIS berturut turut adalah $0.37 \mathrm{U} / \mathrm{ml}$ dan $0.032 \mathrm{U} / \mathrm{ml}$. Perbandingan substrat:enzyme: 1.2:1, pada substrat BIS $1.5 \%$ memberikan derajat polimerisasi terbaik bagi produksi oligosakarida. Prebiotik MOS ini dapat mempengaruhi pertumbuhan Escherichia coli patogen dan Lactobacillus casei. E. coli tidak dapat menggunakan prebiotik ini sebagai sumber karbon dibandingkan $L$. casei. Substitusi sumber karbon dengan prebiotik menurunkan kemampuan $L$. casei dalam memproduksi asam organik. Disimpulkan bahwa isolat lokal A2 (B. borstelensis) menghasilkan mananase yang dapat digunakan untuk menghasilkan prebiotik dari BIS.

Kata kunci: Brevibacillus borstelensis, mananase, Lactobacillus casei, PKC

\section{INTRODUCTION}

Palm oil processing produces by-products such as palm kernel cake (PKC), which can reach $45 \%-46 \%$ of palm kernel. PKC generally contains approximately $15.4 \%$ crude protein and $16.4 \%$ crude fiber (Adrizal et al.,

${ }^{*}$ Corresponding author:

E-mail: ameryandini@yahoo.com
2011). Approximately $20 \%-40 \%$ of the fiber composition of palm kernel cake is in the form of $\beta$-mannans (Yopi et al., 2006). This abundant by-product of palm oil industry is used as animal feed. Due to its high content of hemicellulose (mannan and galactomanan) and low essential amino acids contents, the use of palm kernel cake in animal feed is limited to ruminant animals (Yopi et al., 2006, Sakamoto \& Toyohara, 2009).

The use of antibiotics in the feed has been banned in European Union since 2006. This is due to the con- 
cern of either antibiotic residues or antibiotic-resistant microorganisms in the human body or livestock (especially pathogenic bacteria such as Salmonella, E. coli and Clostridium perfringens). Prebiotics and probiotics have been used as alternatives to replace the use of antibiotics in animal feed (Reid \& Robert, 2002; Samadi, 2002; Urashima \& Taufik, 2010). The use of prebiotics can increase the number of beneficial bacteria in the intestine such as Lactobacillus and Bifidobacterium, therefore suppressing the growth of pathogen and increasing resistance to infection. Mannan can be hydrolyzed into manno-oligosaccharides (MOS), a type of prebiotics. In the previous report, supplementation of the diet with MOS showed a significant reduction of the total population of E. coli and Salmonellae in the broiler chicken feces (Khanongnuch et al., 2006). The balance of intestinal microflora was also related to MOS supplementation. This has beneficial effect in enhancing the growth of desirable microorganisms and thus may stimulate immune system (Shashidhara \& Devegowda, 2003). A study was then conducted to evaluate the capability of mannanolytic bacteria to use PKC as the mannan sources to produce manno-oligosaccharide prebiotics. This study was also aimed at characterizing the mannanolytic enzyme.

\section{MATERIALS AND METHODS}

\section{Enzyme Characterization}

A2 isolate isolated from soils around the IPB campus has been shown to have the ability to use PKC as a carbon source. As the main culture, isolates were grown in a medium containing locust bean gum (LBG) $(0.5 \%)$, $\mathrm{KNO}_{3}(0.2 \%), \mathrm{K}_{2} \mathrm{HPO} 4,(0.1 \%), \mathrm{MgSO}_{4}(0.05 \%), \mathrm{NaCl}$ $(0.05 \%), \mathrm{FeSO}_{4}(0.001 \%)$ and $\mathrm{CaCO}_{3}(0.3 \%)$ for $3 \mathrm{~d}$. LBG is a common medium for producing mannanase. Main cultures were then sub-cultured into $100 \mathrm{ml}$ of LBG liquid medium in $500 \mathrm{~mL}$ flask and further incubated in a shaker incubator (120 rpm speed). Crude extract was obtained from each culture by centrifugation at $3000 \mathrm{~g}$ for $25 \mathrm{~min}$. The enzyme activity of crude extract was measured by using DNS method (Miller, 1959), with mannose as the standard. The amount of reducing sugars yield was assessed by spectrophotometry analysis (540 nm).

Crude extracts were used as the enzyme source, and further be examined for mannanolytic activity at various $\mathrm{pH}$ ranging from 3 to 8.5 , and temperature ranging from $30{ }^{\circ} \mathrm{C}$ to $90^{\circ} \mathrm{C}$. The ability of enzyme to hydrolyze PKC was tested at its optimum temperature and $\mathrm{pH}$ obtained previously. The concentration of PKC tested varied $(0.5 \%, 1.0 \%$, and $1.5 \%)$. The dynamic of hydrolyzing activity was measured every $24 \mathrm{~h}$, based on the amount of reducing sugar, total sugar and the degree of polymerization (DP) of the hydrolyzed products.

\section{The Influence of Manno-oligosaccharides Prebiotic on the Growth of Lactic Acid and Pathogenic Bacteria}

The effectiveness of manno-oligosaccharides prebiotic produced from PKC hydrolyzation was further tested against bacterial growth. One colony of either lactic acid bacteria or pathogenic bacteria were grown in LB or MRS liquid medium, respectively, and incubated at 37 ${ }^{\circ} \mathrm{C}$ for $24 \mathrm{~h}$. There were six treatment groups, designated as 1: L. casei in minimum MRS media (glucose concentration was reduced to one-tenth), 2: L. casei in minimum MRS which glucose was substituted with prebiotic, 3: $L$. casei in MRS medium, 4: E. coli in minimum LB medium (trypton concentration was reduced to one-tenth), 5: E. coli in minimum LB medium substituted with prebiotics (tripton was substituted with prebiotics), 6: E. coli in LB media. After incubation, cell's population was calculated in each treatment based on TPC method. Prebiotic which substituted glucose had a DP about 12 and had an equal concentration with glucose. All data were analyzed using descriptive analysis.

\section{Volatile Fatty Acids}

The volatile fatty acids (VFA) production of LAB using prebiotics as a substrate was measured using a Chrompack 9002 gas chromatograph. The VFA production indicates the growth of bacteria and its ability to use carbon sources available.

\section{S-rRNA Gene Analysis}

Isolate A2 was identified based on molecular methods. Genomic DNA was isolated using standard CTAB method as described by Sambrook et al. (1989). Genomic DNA was then used for PCR amplification by using 16S-rRNA specific primer as follows: 63f (5'CAG GCC TAA CAC ATG CAA GTC - 3') and 1387r (5'- GGG CGG WTG GTA CAA GGC-3') (Marchesi et al., 1998). DNA amplification was conducted for 30 cycles with following condition: pre denaturation for $2 \mathrm{~min}$ at $94{ }^{\circ} \mathrm{C}$, denaturation at $92{ }^{\circ} \mathrm{C}$ for $30 \mathrm{~s}$, annealing at $55^{\circ} \mathrm{C}$ for $30 \mathrm{~s}$, extension at $75{ }^{\circ} \mathrm{C}$ for $1 \mathrm{~min}$. PCR product was used for DNA electrophoresis by using $1 \%$ agarose gel and further visualized by using EtBr staining and UV illumination. DNA amplicon was further lead to DNA sequencing. Homology analysis was done by using Basic Local Alignment Tools (BLASTN) method on GenBank database.

\section{RESULTS AND DISCUSSION}

The daily activity of mannanase derived from the crude extract of isolate $\mathrm{A} 2$ was tested at $\mathrm{pH} 7$ and $30{ }^{\circ} \mathrm{C}$ using either LBG (Figure 1) or PKC (Figure 2) as the main substrate. The highest mannanase production was achieved on day- 6 with activity of $0.37 \mathrm{U} / \mathrm{mL}$ and in day -4 with activity of $0.032 \mathrm{U} / \mathrm{mL}$ in both LBG and PKC as substrates respectively. LBG consists of galactomannan and galactose, so high enzyme activity indicates the enzymes ability to degrade galactomannan. PKC is a complex medium which consists of $\beta$-mannan, xylan, arabinan and cellulose (Oluwafemi, 2009; Sakamoto \& Toyohara, 2009). Different ability to degrade mannan substrate has been shown by isolate RA05 which was not able to degrade mannan of sugar palm but it had the activity on PKC (Meryandini et al., 2010). Bacillus subtilis WY34 exhibited high activity on galactomannan from 


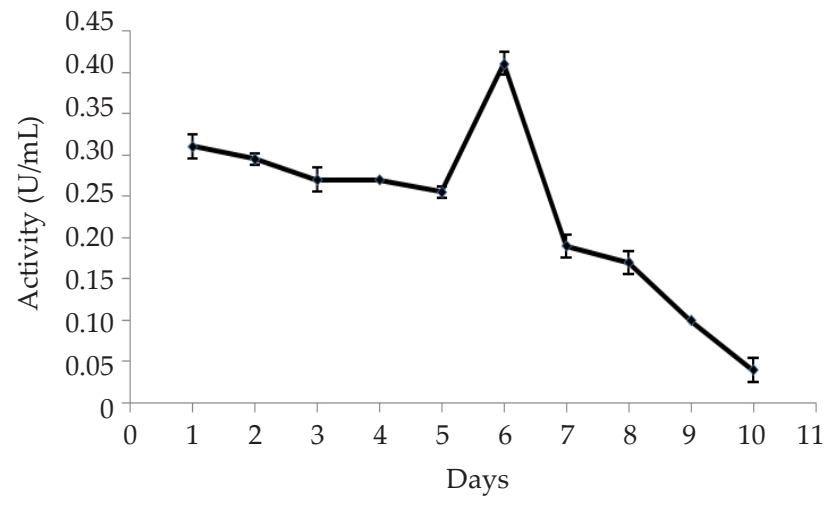

Figure 1. Mannanase activity curve from $\mathrm{A} 2$ isolate at $\mathrm{pH} 7$ and $30{ }^{\circ} \mathrm{C}$ on LBG $0.5 \%$

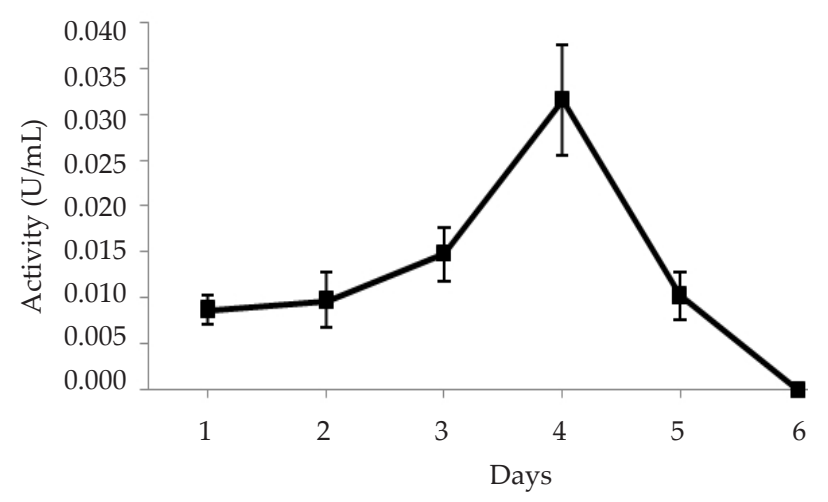

Figure 2. Mannanase activity curve from $\mathrm{A} 2$ isolate at $\mathrm{pH} 7$ and $30{ }^{\circ} \mathrm{C}$ on PKC $0.5 \%$

LBG $(100 \%)$, but just $56.8 \%$ in Konjac powder, $20.4 \%$ in copra mannan and $10.7 \%$ in guar gum galactomannan (Jiang et al., 2006). The optimum time of mannanase production was then used as the standard for the harvesting time of bacterial cells crude extract in the following mannanase production.

Mannanase production from isolate A2 had the highest activity at $90{ }^{\circ} \mathrm{C}$ and $\mathrm{pH} 7(0.256 \mathrm{U} / \mathrm{mL})$ when compared to the activity of this enzyme at different $\mathrm{pH}$ and temperature (Table 1). Moreover, mannanase of isolate A2 also showed high activity at $\mathrm{pH} 8$ (0.253 $\mathrm{U} / \mathrm{mL}$ ) when measured at $90{ }^{\circ} \mathrm{C}$. Similar thermophilic mannanase enzyme had been isolated from Thermotoga neapolitana 5068 that had the optimum temperature at $87^{\circ} \mathrm{C}$ (Duffaud et al., 1997).

Increase in temperature leads to the increase in thermal energy of the substrate molecule and thus increases the rate of enzyme reactions. Acidic or alkaline $\mathrm{pH}$ conditions affect the ionization of the active enzyme that will affect the affinity of the enzyme to the substrate and the enzymatic reaction rate. However, in this study, mannanase of isolate A2 was observed to have lower activity when using PKC as the substrate compared to LBG. It might be due to the differences in chemical content of the PKC and LBG that may affect the enzymatic activity. As previously reported, LBG consists of galactomannan and galactose, while the composition of PKC besides $\beta$-mannan are xylan, arabinan and cellulose (Oluwafemi, 2009; Sakamoto \& Toyohara, 2009).
Table 1. Mannanase activity on $0.5 \%$ LBG medium at different $\mathrm{pH}$ and temperature

\begin{tabular}{|c|c|c|}
\hline Temperature $\left({ }^{\circ} \mathrm{C}\right)$ & $\mathrm{pH}$ & Activity $(\mathrm{U} / \mathrm{mL})$ \\
\hline \multirow[t]{6}{*}{30} & 3 & 0.000 \\
\hline & 4 & 0.000 \\
\hline & 5 & 0.131 \\
\hline & 6 & 0.084 \\
\hline & 7 & 0.058 \\
\hline & 8 & 0.131 \\
\hline \multirow[t]{6}{*}{40} & 3 & 0.000 \\
\hline & 4 & 0.000 \\
\hline & 5 & 0.132 \\
\hline & 6 & 0.021 \\
\hline & 7 & 0.124 \\
\hline & 8 & 0.148 \\
\hline \multirow[t]{6}{*}{50} & 3 & 0.000 \\
\hline & 4 & 0.000 \\
\hline & 5 & 0.000 \\
\hline & 6 & 0.106 \\
\hline & 7 & 0.112 \\
\hline & 8 & 0.117 \\
\hline \multirow[t]{6}{*}{60} & 3 & 0.000 \\
\hline & 4 & 0.000 \\
\hline & 5 & 0.000 \\
\hline & 6 & 0.068 \\
\hline & 7 & 0.131 \\
\hline & 8 & 0.033 \\
\hline \multirow[t]{6}{*}{70} & 3 & 0.000 \\
\hline & 4 & 0.000 \\
\hline & 5 & 0.000 \\
\hline & 6 & 0.000 \\
\hline & 7 & 0.073 \\
\hline & 8 & 0.033 \\
\hline \multirow[t]{6}{*}{80} & 3 & 0.000 \\
\hline & 4 & 0.000 \\
\hline & 5 & 0.000 \\
\hline & 6 & 0.059 \\
\hline & 7 & 0.124 \\
\hline & 8 & 0.063 \\
\hline \multirow[t]{6}{*}{90} & 3 & 0.000 \\
\hline & 4 & 0.000 \\
\hline & 5 & 0.091 \\
\hline & 6 & 0.227 \\
\hline & 7 & 0.256 \\
\hline & 8 & 0.253 \\
\hline
\end{tabular}

The best degree of polymerization (DP) was obtained after $72-\mathrm{h}$ of incubation, with the ratio of substrate (1.5\% PKC) : enzyme was 1.2: 1 Table 2$)$. This 
condition was further used for optimum production of oligosaccharides.

One way to test the prebiotics produced from PKC was its ability to enhance the growth of BAL and to depress the growth of E. coli. The ability of E. coli to use prebiotics as the carbon and energy sources was analyzed for $48 \mathrm{~h}$. In the first $24 \mathrm{~h} \mathrm{E}$. coli was still able to grow in the minimum LB media without the prebiotic or prebiotics substitution. It might be due to the ability of E. coli to continue their metabolism after grown on LB medium. Prebiotics used as carbon source was calculated through degree of polymerization so it could consist of small fraction of short chains of monosaccharides or oligosaccharides that were easily digested by $E$. coli. Numbers of cells in minimum LB medium $\left(4 \times 10^{7}\right.$ cells $/ \mathrm{mL})$ was lower than that in LB medium $\left(2.3 \times 10^{15}\right.$ cells/mL). Interestingly, substitution of prebiotics in minimum LB medium increased cells viability, whereas population of E. coli in LB medium containing prebiotics was approximately $3.5 \times 10^{11}$ cells/mL. Similarly, L. casei was also found to be more viable in minimum MRS medium supplemented with prebiotics $\left(1.1 \times 10^{8}\right.$ cells/ $\mathrm{mL})$ compared to without prebiotics treatment $\left(2 \times 10^{7}\right.$ cells/mL). However, these number of cell's population were still lower compared to the growth of L. casei in its rich MRS medium $\left(1.08 \times 10^{14}\right.$ cells $\left./ \mathrm{mL}\right)$. In addition, $\mathrm{pH}$ value of the culture in rich MRS medium was lower $(\mathrm{pH}=3.55)$ than those cultures in minimum MRS medium (6.39 and 6.55) with and without prebiotics substitutions, respectively.

To further study the growth of E. coli at the next $24 \mathrm{~h}$ in minimum medium containing prebiotics, E. coli was sub-cultured from minimum LB medium to a new similar medium. In contrast to its earlier $24 \mathrm{~h}$ studies, the growth of $E$. coli in minimum LB medium containing prebiotics $\left(4 \times 10^{7}\right.$ cells $\left./ \mathrm{mL}\right)$ was lower than those

Table 2. Degree of polymerization (DP) of PKC using mannanase A2 (substrate : enzyme $=1.2: 1$ )

\begin{tabular}{ccccc}
\hline $\begin{array}{c}\text { PKC } \\
\text { concentration }\end{array}$ & Hour & $\begin{array}{c}\text { Total } \\
\text { sugar }\end{array}$ & $\begin{array}{c}\text { Reducing } \\
\text { sugar }\end{array}$ & DP \\
\hline $0.50 \%$ & 1 & 3.786 & 0.264 & 14.357 \\
& 24 & 3.851 & 0.370 & 10.417 \\
& 48 & 2.113 & 0.186 & 11.381 \\
& 72 & 7.629 & 0.519 & 14.709 \\
& 96 & 9.041 & 0.488 & 18.540 \\
$1.00 \%$ & 1 & 3.851 & 0.304 & 12.680 \\
& 24 & 5.013 & 0.614 & 8.168 \\
& 48 & 5.197 & 0.318 & 16.360 \\
& 72 & 7.839 & 0.583 & 13.453 \\
& 96 & 10.703 & 0.591 & 18.120 \\
& 1 & 6.229 & 0.324 & 19.244 \\
& 24 & 9.910 & 0.672 & 14.755 \\
& 48 & 5.425 & 0.451 & 12.038 \\
& 72 & 7.426 & 0.679 & 10.942 \\
& 96 & 8.064 & 0.691 & 11.676 \\
\hline
\end{tabular}

without prebiotics treatment $\left(3 \times 10^{9}\right.$ cells $\left./ \mathrm{mL}\right)$. After the first $24 \mathrm{~h}$ of growth $E$. coli was not able to maintain their growth because they could not use prebiotics compared to the growth of E. coli on LB minimum which still contained a low level of tripton (1\%). Thus, suggesting that E. coli could not use prebiotics as the carbon sources. In the case of L. casei, co-inoculation of culture from minimum MRS medium containing prebiotics to the same medium also affected bacterial cell viability. Contrary to the response of E. coli, L. casei was observed to have better growth in minimum MRS medium containing prebiotics $\left(1.4 \times 10^{11}\right.$ cells $\left./ \mathrm{mL}\right)$ compared to those without prebiotics treatment $\left(3.2 \times 10^{10}\right.$ cells $\left./ \mathrm{mL}\right)$. These results indicated that $L$. casei could utilize prebiotics as the carbon source. It has been previously reported that L. casei can produce several types of enzymes that enable the bacteria to utilize oligosaccharides such as $\alpha$-galactosidase, $\alpha$--mannosidase, $\beta$-glucosidase, $\alpha$-glucosidase, and $\beta$-galactosidase (Arora et al., 1990).

The growth of $L$. casei in the first $24 \mathrm{~h}$ was lower compared to the growth of E. coli as shown in total colony formed. However, in the next $24 \mathrm{~h}, \mathrm{~L}$. casei seemed to grow faster than E. coli. In vitro test using XOS as a prebiotics for accelerating the growth of Bifidobacteria was also done by Zeng et al. (2007) and Su et al. (2007). Baurhoo et al. (2007) and Kim et al. (2011) also reported that provision of prebiotics increased the number of probiotic bacteria. Moreover, Khanongnuch et al. (2006) and Baurhoo et al. 2009 also reported that population of E. coli and salmonellae in chicken faeces decreased significantly due to the effect of MOS. Therefore, the effect of stimulating the growth of L. casei and suppressing the growth of $E$. coli can be tested in vivo by prebiotic administration on an ongoing basis so that its influence to intestinal microflora balance can be determined.

Carbohydrate fermentation by $L$. casei produced metabolites of organic acids such as short chain fatty acids. Analysis of VFA was particularly aimed to determine the amount of short-chain fatty acids produced by L. casei on MRS medium with prebiotics as well as on MRS media.

Total short chain fatty acids production in MRS culture $(22.72 \mathrm{mmol})$ was higher than those in the MRS culture with prebiotics substitution $(12.06 \mathrm{mmol})$. These results were also supported with $\mathrm{pH}$ measurement data, in which the $\mathrm{pH}$ of culture in MRS medium with prebiotics was higher (6.39) than the $\mathrm{pH}$ in MRS medium (3.55). In the MRS medium the BAL fermented glucose (monomer) and produced organic acid whereas in the MRS medium with prebiotics, the glucose was substituted with prebiotics (polymer). Low concentration of short chain fatty acids of culture grown in MRS medium with prebiotics (Table 3 ) was probably caused by modification or changes in certain metabolism pathways since MOS was used as the only carbon source replacing glucose. However, L. casei was still able to grow in this medium. In addition, the degree of polymerization value (DP) of the prebiotic MOS ranged from 8 to10, which was still higher than the commonly used prebiotics, which is about 3-7 with a purity of 95\% (Pan et al., 2009). Hence, it would affect the capability of probiotic bacteria to do 
Table 3. Volatile fatty acids (VFA) contents of MRS and MRS added prebiotics

\begin{tabular}{lrrrrrr}
\hline \multirow{2}{*}{ Sample } & \multicolumn{5}{c}{ VFA $(\mathrm{mM})$} \\
\cline { 2 - 7 } & $\begin{array}{c}\text { Acetic } \\
\text { acid }\end{array}$ & $\begin{array}{c}\text { Propi- } \\
\text { onate } \\
\text { acid }\end{array}$ & $\begin{array}{c}\text { Iso } \\
\text { butirate }\end{array}$ & $\begin{array}{c}\text { n- } \\
\text { butirate }\end{array}$ & $\begin{array}{c}\text { Iso } \\
\text { valerat }\end{array}$ & $\begin{array}{c}\text { n- } \\
\text { valerat }\end{array}$ \\
\hline MRS & 113.54 & 5.06 & 1.48 & 1.89 & 0.75 & 0.0 \\
MRS with & 6.13 & 2.94 & 0.72 & 1.78 & 0.52 & 0.0 \\
prebiotics & & & & & & \\
\hline
\end{tabular}

fermentation which further lowers the amount of fermentation products, including organic acids.

Based on homology analysis, isolate A2 possessed high similarity with Brevibacillus borstelensis (100\%). Brevibacterium borstelensis was equivalent with Bacillus borstelensis (Shida et al., 1996). B. borstelensis was also known as keratinase and lipase producing bacteria (Hoq et al., 2005; Panda et al., 2011).

\section{CONCLUSION}

Local A2 isolate (B. borstelensis) produces mannanase which can be used to produce prebiotics from palm kernel cake (PKC). The manno-oligosaccharides prebiotics can enhance the growth of $L$. casei and suppress $E$. coli growth.

\section{REFERENCES}

Adrizal A., Y. Yusrizal, S. Fakhri, W. Haris, E. Ali, \& C. R. Angel. 2011. Feeding native laying hens diets containing palm kernel meal without enzyme suplementation: 1 . Feed conversion ratio and egg production. Appl. Poult. Res. 20: 40-49. http://dx.doi.org/10.3382/japr.2010-00196

Arora, G., B. H. Lee, \& M. Lamoureux. 1990. Characterization of Enzyme Profiles of Lactobacillus casei Species by a Rapid API ZYM System. J. Dairy Sci. 73:264-279. http://dx.doi. org/10.3168/jds.S0022-0302(90)78669-9

Baurhoo, B., L. Phillip, \& C. A. Ruiz-Feria. 2007. Effect of purified lignin and mannan oligosaccahrides on intestinal integrity and microbial populations in the ceca and litter of broiler chickens. Poul. Sci. 86: 1070-1078.

Baurhoo, B., P. R. Ferket, \& X. Zhao. 2009. Effect of diets containing different concentration of mannanoligosaccharide or antibiotics on growth performance, intestinal development, cecal and litter microbial populations and carcass parameters of broilers. Poult. Sci. 88: 2262-2272. http:// dx.doi.org/10.3382/ps.2008-00562

Duffaud, G. D., C. M. Mc Cutchen, P. Leduc, K. N. Parker, \& R. M. Kelly. 1997. Purification and characterization of extremely thermostable $\beta$-mannanase, $\beta$-mannosidase, and $\alpha$-galactosidase from the hyperthermophilic eubacterium Thermotoga neopolitana 5068. Appl. Environ. Microbiol. 63:169-177.

Hoq, Md. M., K. A. Z. Siddiquee, H. Kawasaki, \& T. Seki. 2005. Keratinolytic activity os some newly isolated Bacillus species. J. Biol. Sci. 5:193-200. http://dx.doi.org/10.3923/ jbs.2005.193.200

Jiang, Z., Y. Wei, D. Li, L. Li, P. Chai, \& I. Kusakebe. 2006. High level production, purification and characterization of thermostable $\beta$-mannanase from the newly isolated Bacillus subtilis WY34. Carbohydrate Polymers 66:88-96. http:// dx.doi.org/10.1016/j.carbpol.2006.02.030
Khanongnuch, C., C. Sa-nguansook, \& S. Lumyong. 2006. Nutritive quality of $\beta$-mannanase treated copra meal in broiler diets and effectiveness on some fecal bacteria. J. Poult. Sci. 5:1087-1091.

Kim, G. B, Y. M. Seo, C. H. Kim, \& I. K. Paik. 2011. Effect of dietary prebiotic supplementation on the performance, intestinal microflora, and immune response of broiler. Poult. Sci. 90:75-82. http://dx.doi.org/10.3382/ps.2010-00732

Marchesi, J. R., T. Saho, A. J. Weightman T. A. Martin, J. C. Frey, S. J. Hiom, D. Dymock, \& W. G. Wade. 1998. Design and evaluation of useful bacterium-specific PCR primers that amplify genes coding for bacterial 16SRNA. Appl. Environ. Microbiol. 64: 795-799.

Meryandini, A., R. Anggreandari, \& N. Rachmania. 2010. Isolation of mannanolitic bacteria and characterization of its mannanase. Biota 13:82-88.

Miller, G. L. 1959. Use of dinitrosaiicyiic acid reagent for determination of reducing sugar. Anal. Chem. 31:426-428. http://dx.doi.org/10.1021/ac60147a030

Oluwafemi, R. A. 2009. Palm kernel cake (PKC) utilization in monogastric animal feeding - implications for sustainable livestock development. The Internet Journal of Veterinary Medicine $^{\mathrm{TM}}$. Vol 6: 2

Pan, X., F. Chen, T. Wu, H. Tang, \& Z. Zhao. 2009. Prebiotic oligosaccharides change the concentrations of short-chain fatty acids and the microbial population of mouse bowel. J Zhejiang Univ. Sci. B 10:258-263. http:// dx.doi.org/10.1631/ jzus.B0820261

Panda, A. K., S. P. S. Bisht, \& A. K. Panigrahy. 2011. Isolation and identification of an extracellular alkali stable lipase producing thermophilic Brevibacillus sp. AK-P2 from an Indian hot spring. Adv. Biotech 10: 25-29.

Reid, G. \& F. Robert. 2002. Alternatives to antibiotic use: Probiotics for the gut. Anim Biotechnol. 13: 97 - 112. http:// dx.doi.org/10.1081/ABIO-120005773

Sakamoto H. \& H. Toyohara. 2009. A comparative study of cellulose and hemicellulase activities of brackish water clam Corbicula japonica with those of other marine Vineroida bivalves. J. Exp. Biol. 212:2812-2818. http://dx.doi. org/10.1242/jeb.031567

Samadi. 2002. Probiotik pengganti antibiotik dalam pakan ternak. [terhubung berkala]. http://www.ppi-goettingen.de/ mimbar/kliping/probiotik.html

Sambrook, J., E. F. Fritsch, \& T. Maniatis. 1989. Molecular Cloning: A Laboratory Manual. $2^{\text {nd }}$ Ed. Cold Spring Harbor Laboratory Press, USA.

Shashidhara, R. G. \& G. Devegowda. 2003. Effect of dietary mannan oligosaccharide on broiler breeder production traits and immunity. Poult. Sci. 82: 1319-1325.

Shida, O., H. Takagi, K. Katowaki, \& K. Komagata. 1996. Proposal for two ner genera, Brevibacillus gen. nov and Aneurinibacillus gen. nov. Int. Syst. Bacteriol. 46:939-946. http:// dx.doi.org/10.1099/00207713-46-4-939

Su, P., A. Hendriksson, \& H. Mitcell. 2007. Selected prebiotics support the growth of probiotic, monocultures in vitro. Anaerobes 13:134-139. http://dx.doi.org/10.1016/ j.anaerobe.2007.04.007

Urashima, T. \& E. Taufik. 2010. Oligosaccharides in milk: their benefits and future utilization. Med. Pet. 33:189-197. http:// dx.doi.org/10.5398/medpet.2010.33.3.189

Yopi, A. P., A. Thontowi, H. Hermansyah, \& A. Wijanarko. 2006. Preparasi mannan dan mannanase kasar dari bungkil kelapa sawit. J. Teknol. 4: 312-319.

Zeng, H., Y. Xue, T. Peng, \& W. Shao. 2007. Properties of xylanolytic enzyme system in Bifidobacteria and their effects on the utilization of xylooligosaccharides. Food Chem. 101:11721177. http://dx.doi.org/10.1016/j.foodchem.2006.03.019 